\title{
Comparative Analysis Of The Morphometric And Meristic Character Of Lutjanidae From Lekki And Badagry Lagoons In Lagos State Nigeria.
}

\author{
Fakunmoju F.A, Akintola S.L, Boboye Ijimakinde \\ Dept Of Fisheries, Lagos State Polytechnic Ikorodu, Lagos State. \\ Dept Of Fisheries, Faculty Of Science Lagos State University, Ojo.
}

\begin{abstract}
Due to identification problem that exist between fishes of different species, hence the need to compare the morphometric and meristic character of lutjanidae, L. goreensis (valenciennes 1830) and L. agennes (Blecker 1863) from Lekki lagoon and Badagry creek of Lagos State Nigeria. The lutjanids L. goreensis and L. agennes is one of the fish species that contribute to the fisheries of Lagos Lagoon.

A total of 120 samples (60 from lekki and 60 from badagry) were caught from the two (2) sampling stations located in the Lagoon of Lagos State. Morphometric measurements and meristic characters were determined on the specimens to ascertain the possibility of morphological and meristic diversity among them. The morphometric measurements i.e. eye diameter $(E D)$ for $L$. goreensis varied from $1.7-2.5 \mathrm{~cm}$, while $L$. agennes was $1.3-2.2 \mathrm{~cm}$; head length $(H L)$ in L. goreensis was $8.8-11.2 \mathrm{~cm}$ while L. agennes was $3.7-11.2$; body depth $(B D)$, in L. goreensis it was $10.2-17.9 \mathrm{~cm}$ while L. agennes was $3.8-15.5 \mathrm{~cm}$; standard length $(S L)$, in L.goreensis was $19-23.5 \mathrm{~cm}$ while that of L.agennes wasl1.7 - $23 \mathrm{~cm}$ and total length $(T L)$, in L.goreenis was $28.5-35 \mathrm{~cm}$ while that of L.agennes was $14.2-35 \mathrm{~cm}$. The meristic characters of the species included 10 dorsal spines for L.goreensis, 14 rays in the posterior dorsal fin; 3 was also recorded for the anal spine and 8 rays in the posterior anal fin, same value were also obtain in L. agennes except for a little difference in the number of scales with L.goreensis having $36-60$ and L. agennes showing $36-58$. The populations of the species from the two (2) sampling stations in the lagoon showed variations in morphometric measurements and similarities in meristic counts but these did not differ significantly $(P>0.05)$ indicating that species from the stations may not be genetically diversed. These insignificant variations may be related to the geographical ecological activities of the lagoon.
\end{abstract}

In the present study there was no taxonomic variation among the two species of fish $\quad L$. goreensis and L. agennes in Lagos Lagoon based on the stated methodology.

In furtherance of this work, a research programme must be embarked upon at molecular level of analysis (e.g. Randomly Amplified Polymorphic DNA (RAPD) primers, RAPD markers) which may provide better or more precise results on genetic and morphological diversities among the species of this fishes in Lagos Lagoon, Nigeria.

Keywords: Lutjanidae, morphometric and meristic characters, lagoons, creeks, diversity, comparative analysis

\section{Introduction}

Fish is one of the cheapest sources of animal protein and it accounts for about $40 \%$ of the total animal protein intake in the average Nigeria. According to Eyo (2010), fish muscle is very rich in high quality protein, containing 15 to $20 \%$ protein.

The genus lutjanidae commonly called the 'snappers' of the family of perciform fish are mainly marine fishes but with some members inhibiting the estuaries feeding in freshwater. They are known to stay relatively close to the bottom and inhabit rocky bottom, ledges, ridges and artificial reefs including offshore rigs and shipwrecks. It is of great commercial importance (Olatunde 1989). Lutjanidae are highly valued species among the rich in the society because of it's nutritional quality and fleshy body, selling for as high as US\$20 per $\mathrm{kg}$ (Allen 1985).

Allen (1985) have studied some biological aspect of this species. In fish, identification may be determined based on two factors which are morphometric and meristic characters. Mostly the morphometric means of determining the growth rate of the fish is carried out by measuring some parts of the physiological structures of the fishes, while meristic is determined by performing some numerical counts on the fish in order to determine the species and class of the fish.

In lutjanidae, the common adult length is usually $60 \mathrm{~cm}$ but may extend to $100 \mathrm{~cm}$. The fish lutjanidae is estimated to have 10 spines, 14 soft dorsal rays, 3 anal spines and 8-9 anal soft rays, which is a determinant features that distinguished lutjanids from other similar fishes especially the so called popular lady fish (Allen 1985). 
Hence the need for the research which is aimed at investigating the comparative analysis of the morphometric and meristic characters of lutjanidae from two different water bodies of Lagos state.

\section{STUDY AREA}

\section{Materials And Methods}

Lekki lagoon is located between longitude $2^{0} 42^{\prime} \mathrm{E}$ and $3^{0} 22^{\prime} \mathrm{E}$ and latitude $6^{0} 22^{\prime}$ and $6^{0} 20{ }^{\prime} \mathrm{N}$. While Badagry lagoon is located between longitude $3^{0} 0^{\prime}$ and $3^{\circ} 45^{\prime} \mathrm{E}$ and latitude $6^{0} 25^{\prime}$ and $6^{0} 42^{\prime} \mathrm{N}$. These two lagoons serves as feeders through the tidal estuary to the lagos lagoon which then emptied itself into the atlantic ocean via the lagos habour.

The sampling stations used for this study are lekki station and Badagry station which could be seen clearly in the map below.
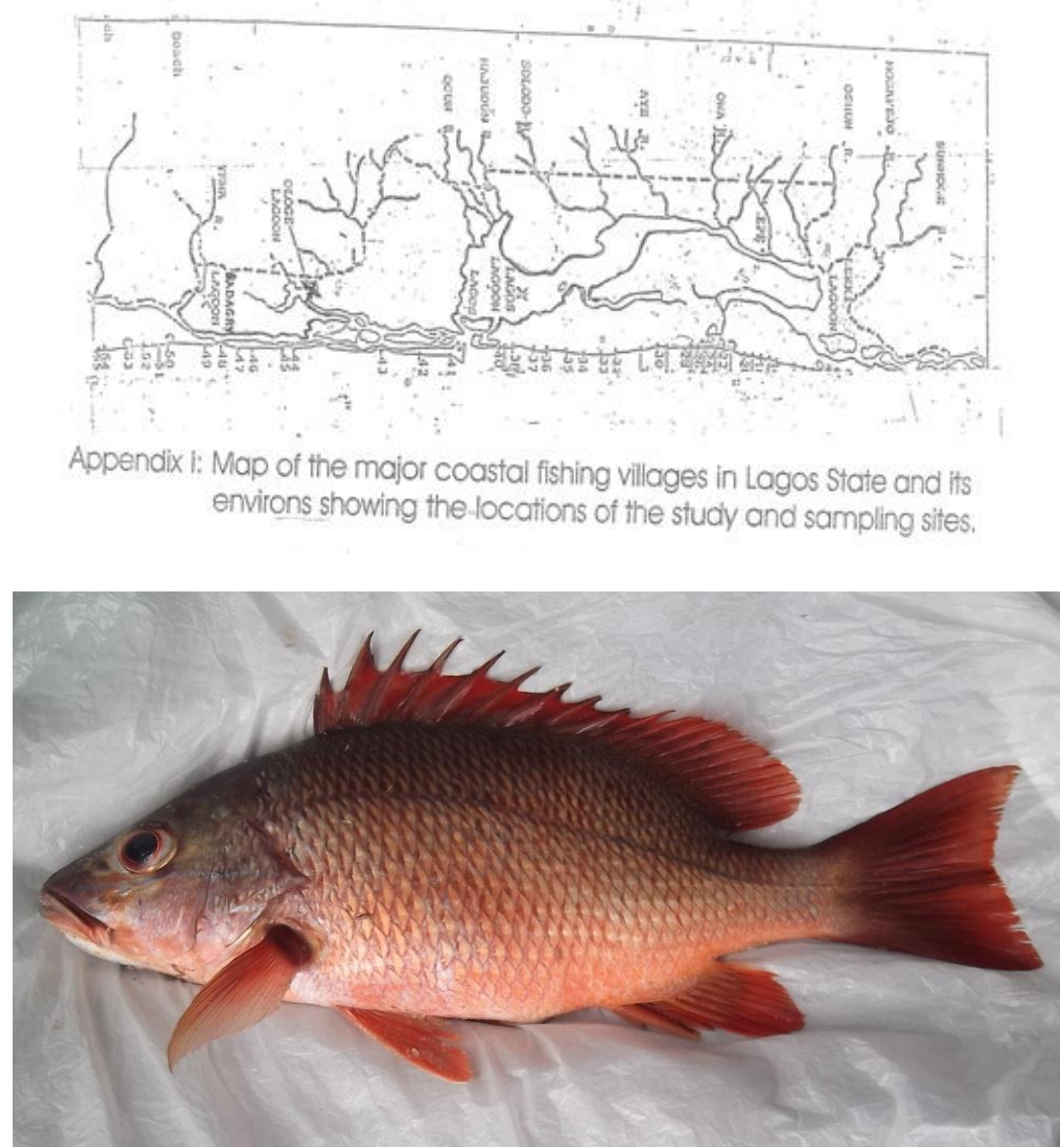

FISH SPECIMEN: Lutjanus goreensis

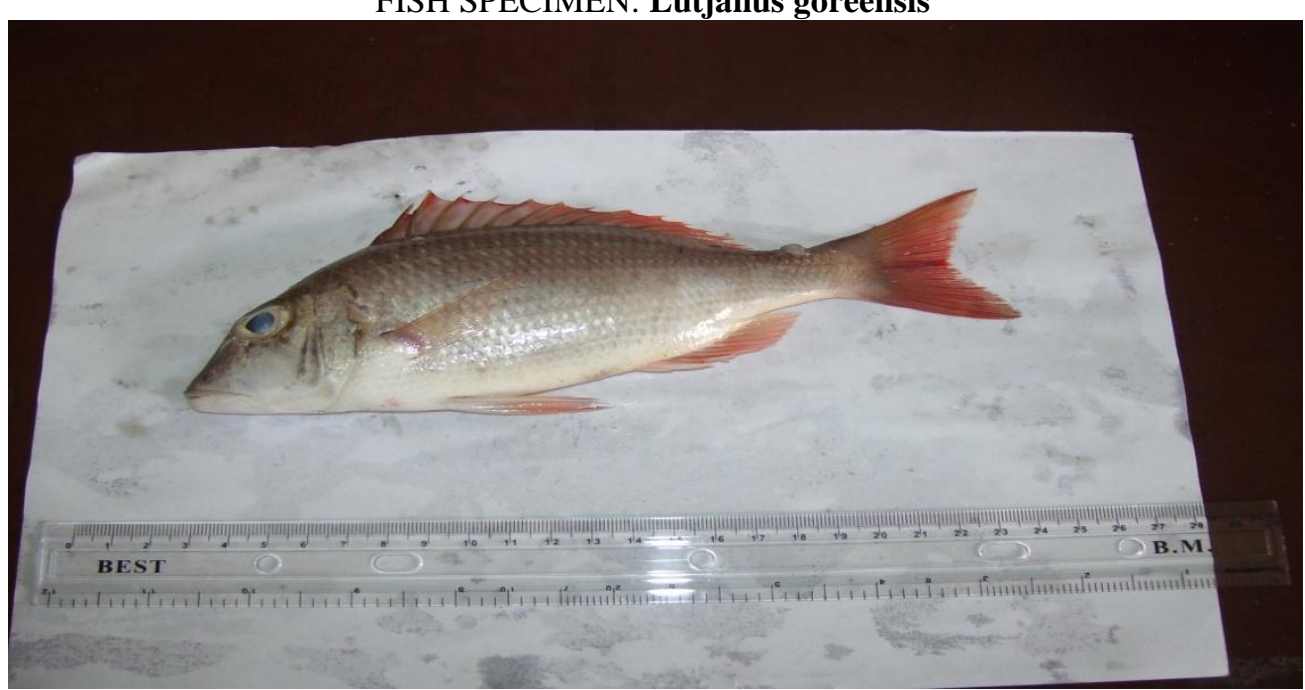

Lutjanus agennes 


\section{Collection And Analysis Of Specimens}

Sixty (60) Specimens from each of the two lagoons were used, totaling one hundred and twenty (120) specimens. These were purchased randomly from artisanal fishermen using gillnet between (March - September 2012). The fish specimen were identified using field guide to Nigerian Fresh water Fishes (Olaosebikan and Raji, 1998); West African Freshwater Fish (Holden and Reed, 1972) and through the web search. The sexes are not differentiated in this study.

A tag number was given to each fish specimen while location and date of collection were noted.

\section{MORPHOMETRIC MEASUREMENTS (AXIAL GROWTH)}

Morphometric measurements as length which quantify axial growth of parts of the fish samples (Fresh) were carried out with the aid of measuring board, ruler and divider. All measurements were conducted with the head of the fish specimen prinking to the left flank (Bagenal 1978).

The following morphometric characters as length were measured and recorded to the nearest centimeters.

TOTAL LENGTH (TL): length of the fish measured from the tip of snout to the posterior extremity of the caudal fin ( Paulin, 1988).

STANDARD LENGTH (SL): Measured from tip of the snout to end of body that is, the base of caudal fin, where the fin rays reach the hypurals (Bagenal 1978; Paulin, 1988).

HEAD LENGTH (HL): The longest measurement from anterior edge of the lip to the most popular part of the bony opercular edge (Paulin, 1988).

BODY DEPTH (BD): Measured at the deepest point from base of the dorsal fin to the ventral part of the abdominal region.

EYE DIAMETER (ED): length of orbit, the greatest distance between the free orbital rims.

PELVIC FIN LENGTH (PVL): length taken from the base to the maximum tip of fin.

\section{MORPHOMETRIC MEASUREMENTS (BULK GROWTH).}

Morphometric measurement of each fish (fresh) specimen as weight which qualifies growth in bulk was carried out in the Laboratory by gravimetric method with the aid of a mettlar balance. This represents total weight recorded to three places of decimal in grammes $(\mathrm{g})$.

\section{MERISTIC MEASUREMENTS OF CHARACTERS}

Meristics measurements take cognisance of the counting of number of certain parts of the fish into consideration. Counts of the following meristic characters were made.

\section{DORSAL SPINES AND RAYS}

The spines are hardened and single shafted, located at the anterior part of the dorsal fin. The dorsal rays are soft and flexible, located towards the posterior part of the dorsal fin. Both are designated by a common letter 'D' (Standing for Dorsal Fin) with the Dorsal Spines (DS) counted and recorded in Roman numerals, while the Dorsal Rays (DR) were counted and recorded in Arabic numerals with two rays that have common root being counted as are (Futch.R.B. and G.E. Brugal 1976, Bagenal 1978).

\section{ANAL SPINES AND RAYS}

The spines are also hardened and single - shafted, located at the anterior part of the anal fin while the rays are soft flexible and located at the posterior part. Both are designated by a common letter 'A' (Standing for Anal fin) with the Anal species (AS) counted and recorded in Roman numerals, and the Anal Ray (AR) counted and recorded in Arabic numerals.

SCALE COUNT This represents the number of dorsal scales in the lateral line scales counts were made according to the procedure described by Bagenal (1978). The Lutjanids have lateral line in single part. Counting was made to the end of upper lateral line.

\section{Methods Of Data Analysis}

The morphometric and meristic characters of the different species from the two locations were collected from the raw data (Appendix II). Computed and analyzed using Ranges, means, mode, standard Errors, percentage, Linear, Regression, correlation coefficient), t- test using Statistical Package for Social Science (S.P.S.S version 17).

The following morphometric relationships were also computed from the data and analyzed using correlation coefficient (r), Linear Regression, Percentage, Ratios. 


\section{LENGTH - WEIGHT RELATIONSHIP (LWR)}

Length of the fish in this case was taken as standard length (SL) in centimetres (cm) against, the total weight (w) in grammes ( $\mathrm{g}$ ). The two measurements were also transferred to logarithm valves. The linear regression equation relating the two measurements is represented by

(i) $\quad \mathrm{W}=\mathrm{aLb}$

(L Standard Length)

$\mathrm{W}=\mathrm{a}+\mathrm{bL}$

(ii). $\quad \log \mathrm{W}=\log \mathrm{a}+\mathrm{b} \log \mathrm{L}$

Length - weight relationship is regarded as an important piece of information required for most computations performed in fisheries stock assessments, and it is widely used by Fisheries researchers viz Sparre.P. Venema.S.C.(1998), Kochzius.M. (1997), Fafioye.O.O and Oluajo.O.A.(2005), Diaz et al (2000) to mention few.

STANDARD LENGTH (SL) - TOTAL LENGTH (TL) RELATIONSHIP.

The linear regression equation relating the two characters is thus

$\mathrm{SL}=\mathrm{a}+\mathrm{bTL}$

Percentage relationship $=\underline{\text { SL }} \times 100$

Ratio Relationship $\quad=\quad \frac{\mathrm{TL}}{\mathrm{SL}}$

HEAD LENGTH (HL) - BODY DEPTH (BD) RELATIONSHIP

The relationship is represented by the linear regression equation as thus:

$\mathrm{HL}=\mathrm{a}+\mathrm{b} \mathrm{BD}$

Percentage relationship $=\underline{\text { HL }} \quad \mathrm{x} \quad 100$

BD

Ratio relationship $=$

$\underline{B D}$

HL

BODY DEPTH (BD) - STANDARD LENGTH (SL) RELATIONSHIP.

The linear regression equation of the relationship is thus

$\mathrm{BD}=\mathrm{a}+\mathrm{bSL}$

Percentage relationship $=\underline{\mathrm{BD}} \quad \mathrm{x} \quad 100$

Ratio relationship $=\quad \underline{\mathrm{SL}}$

SL

BD
HEAD LENGTH (HL) - STANDARD LENGTH (SL) RELATIONSHIP

The linear regression equation of the relationship is represented by

$\mathrm{HL}=\mathrm{a}+\mathrm{bSL}$

Percentage relationship $=\underline{\text { HL }} \quad \mathrm{x} \quad 100$

$\mathrm{SL}$

Ratio Relationship $\quad=\quad \underline{\mathrm{SL}}$

HL

HEAD LENGTH (HL) - TOTAL LENGTH RELATIONSHIP

This is represented by the Linear regression equation

$\mathrm{HL}=\mathrm{a}+\mathrm{bTL}$

Percentage relationship $=\underline{\text { HL }} \quad \mathrm{x} \quad 100$

$\begin{array}{lll} & \mathrm{TL} \\ \text { Ratio relationship } \quad=\quad \mathrm{TL}\end{array}$

$\frac{\mathrm{TL}}{\mathrm{HL}}$

PECTORAL LENGTH (PCL) - TOTAL LENGTH (TL) RELATIONSHIP

The linear regression equation of this relationship is thus.

$\mathrm{PCL}=\mathrm{a}+\mathrm{bTL}$

Percentage relationship $=\underline{\text { PCL }} \times 100$

$\mathrm{TL}$ 
Ratio relationship $=$

TL

PCL

EYE DIAMETER (ED) - HEAD LENGTH (HL) RELATIONSHIP

The linear regression equation relating the two measurements is represented by

$\mathrm{ED}=\mathrm{a}+\mathrm{bHL}$

Percentage relationship $=$ ED $\quad x \quad 100$

Ratio Relationship $\quad=\quad \underline{\mathrm{HL}} \quad \mathrm{ED}$

The parameters ' $a$ ' (intercept) and ' $b$ ' (slope) of the linear regression equation of the relationship in the form $y=$ $a+b x$ stated above and also the correlation co-efficient $(r)$ of the relationships were estimated with the use of Microsoft Excel Linear regression routine on WINDOWS '98'. This is a procedure employed by Kodizius (1997) and S.P.S.S (2007)

The valves of the correlation coefficient ' $r$ ' were tested at 5\% level of significance using degree of freedom DF $=\mathrm{n}-2$ for all relationships, where ' $\mathrm{n}$ ' is the number of samples.

Table values were checked on statistical table values of ' $r$ ' (Spence et al, 1978). Formulae for ratio, range, mean, mode, t-test variance are provided in Appendix III.

\section{Results}

The morphometric measurement in L. goreensis varied between the stations Lekki and Badagry (Table I). Eye diameter (ED) varied from $1.7-2.5 \mathrm{~cm}$; head length, $8.8-11.2 \mathrm{~cm}$; standard length, $19-23.5 \mathrm{~cm}$; body depth, $10.2-17.9 \mathrm{~cm}$; total length, $28.5-35 \mathrm{~cm}$; pectoral length, $7.1-9.0 \mathrm{~cm}$. Data on the body populations of the specimens from the two stations showed that the ratio of total length to standard length of the fish varied between 62.12 and 69.35 in the lagoon. The highest mean of $67.17 \pm 0.75$ and the lowest value of $66.09 \pm 0.39$ were recorded at Lekki and Badagry Station, respectively. The ratio of head length to the total length indicated a range from $28.19-37.86$. The mean valves were $32.60 \pm 0.35$ and $32.62 \pm 0.28$ respectively, for Lekki and Badagry Stations.

Standard length; body depth ratios gave mean valves of $61.40 \pm 1.75$ and $62.44 \pm 1.59$ (Lekki and Badagry) showing that the body depth is smaller than the standard length. The ratio of the eye diameter to head length ranged from 17.92 to 27.41 while the proportion of head length to standard length was 36.05 to 52.68 , which shows that the ratio of the head length in the standard length was more of a proportional size as compared to the standard length.

The ratio of the body depth to head length ranged from 57.04 to 98.13 which shows a little variation in length size. While the ratio of the pectoral length to total length ranged from 23.32 to 30.11 showing that little variation exist between the total length and the pectoral length.

Two-way analysis of variance (t-test) on the morphometric relationship of $L$. goreensis from the sampling station showed that the calculated t-values were -3.404 (SL - TL), 3.420 (HL - BD), -4.333 (BD - SL), -3.217 (HL - SL), -0.101 (HL - TL), 2.728 (ED - HL) and -1.541 (for PCL - TL) and the tabulated t values at 5\% level of significance and degree of freedom of 58 was 2.010. These variations of parameters across the 2 stations were not significantly different $(\mathrm{P}>0.05)$ except in 2 of the parameters HL - BD and ED - HL which were significantly different $(\mathrm{P}>0.05)$.

The morphometric measurements in Lagennes varied between the stations; Lekki and Badagry (Table I). Eye diameter varied from $1.3-2.2 \mathrm{~cm}$, head length, $3.7-11.2 \mathrm{~cm}$, standard length, $11.7-23 \mathrm{~cm}$; body depth, $3.8-15.5 \mathrm{~cm}$, total length, $14.2-35 \mathrm{~cm}$ and pectoral length, $3.5-9.0 \mathrm{~cm}$. Data on the body populations of the specimens from the stations showed that the ratio of standard length to total length of the fish varied between $61.12-83.33$ in the Lagoon. The highest mean of $91.82 \pm 1.32$ and the lowest value of $91.40 \pm 1.32$ were recorded at Lekki and Badagry respectively. The ratio of head length to total length indicated a range from 22.50 to 37.86. The mean ratio were $32.03 \pm 056$ and $3.100 \pm 0.61$ respectively for Badagry and Lekki. Standard length and body depth ration gave mean values of $51.87 \pm 2.02$ and $50.30 \pm 2.11$ (Badagry and lekki) showing that the body depth is smaller than the standard length.The ratio of the eye diameter to the head length ranged from $24.18 \pm 1.02$, while the population of head length to standard length was 31.62 to 52.68 which shows that the ratio of the head length to standard length is more of proportional size as compared to the SL. The ration of the body depth to head length ranged from 72.26 to 103.17 which shows a little variation in length size. While the ratio of the pectoral length to total length ranged from $21.95-30.71$ showing that little variation exist between the total length and the pectoral length. Two-way analysis of variance (t-test) on the morphometric relationships of L.agennes from the sampling stations showed that the calculated t-valves were 0.263 (SL TL), -0.378 (HL - BD), -0.557 (BD - SL), -1.002 (HL - SL), -1.179 (HL - TL), 1.126 (ED -HL) and 0.151 
(PCL $-\mathrm{TL}$ ) and the tabulated $\mathrm{t}$ valves at 5\% level of significance and degree of freedom of 58 was 2.010. These variations of parameters across the 2 stations were not significantly different $(\mathrm{P}>0.05)$.

Table I: Morphometric measurement of L. goreensis and L.agennes from (2) two sampling stations (Lekki lagoon and Badagry creek) of Lagos States Nigeria.

\begin{tabular}{|c|c|c|c|c|c|c|c|c|c|c|c|c|}
\hline \multirow{3}{*}{$\begin{array}{l}\text { MORPHORMET } \\
\text { RIC } \\
\text { MEASUREMEN } \\
\text { T AND BODY } \\
\text { PROPORTION }\end{array}$} & \multicolumn{3}{|c|}{ LEKKI LAGOON } & \multicolumn{3}{|c|}{ LEKKI LAGOON } & \multicolumn{3}{|c|}{ BADAGRY LAGOON } & \multicolumn{3}{|c|}{ BADAGRY LAGOON } \\
\hline & \multicolumn{3}{|c|}{ L. GOREENSIS } & \multicolumn{3}{|c|}{ L. AGENNES } & \multicolumn{3}{|c|}{ L. GOREENSIS } & \multicolumn{3}{|c|}{ L. AGENNES } \\
\hline & $\begin{array}{l}\text { MIN } \\
(\mathrm{cm})\end{array}$ & $\begin{array}{l}\text { MAX } \\
(\mathrm{cm})\end{array}$ & Mean \pm SE & $\begin{array}{l}\text { MIN } \\
(\mathrm{cm})\end{array}$ & $\begin{array}{l}\text { MAX } \\
(\mathrm{cm})\end{array}$ & Mean \pm SE & $\begin{array}{l}\mathrm{MIN} \\
(\mathrm{cm})\end{array}$ & $\begin{array}{l}\text { MAX } \\
(\mathrm{cm})\end{array}$ & Mean \pm SE & $\begin{array}{l}\text { MIN } \\
(\mathrm{cm})\end{array}$ & $\begin{array}{l}\text { MAX } \\
(\mathrm{cm})\end{array}$ & Mean \pm SE \\
\hline Eye diameter (ED) & 1.7 & 2.5 & $2.06 \pm 0.0$ & 1.3 & 2.2 & $1.77 \pm 1.0$ & 1.7 & 2.5 & $1.51 \pm 6.6$ & 1.3 & 2.2 & $1.78 \pm 3.3$ \\
\hline Head length (HL) & 6.2 & 11.2 & $9.86 \pm 3.3$ & 3.7 & 11.2 & $7.85 \pm 0.0$ & 8.8 & 11.2 & $10.1 \pm 1.3$ & 5.2 & 11.2 & $8.42 \pm 3.3$ \\
\hline $\begin{array}{l}\text { Standard length } \\
\text { (SL) }\end{array}$ & 17.2 & 23.5 & $20.9 \pm 0.7$ & 11.7 & 23 & $17.6 \pm 6.0$ & 19 & 23.5 & $21.1 \pm 0.0$ & 12 & 23 & $18.0 \pm 1.3$ \\
\hline Body depth (BD) & 6.9 & 17.9 & $12.9 \pm 2.6$ & 3.8 & 15.5 & $9.21 \pm 3.3$ & 10.2 & 17.9 & $13.2 \pm 4.3$ & 4.8 & 15.5 & $9.66 \pm 6.6$ \\
\hline Total Length (TL) & 22 & 35 & $31.2 \pm 4.0$ & 14.4 & 35 & $24.9 \pm 6.0$ & 28.5 & 35 & $31.9 \pm 7.0$ & 14.2 & 35 & $25.6 \pm 8.6$ \\
\hline $\begin{array}{l}\text { Pectorall fin length } \\
\text { (PCL) }\end{array}$ & 5.2 & 9.2 & $7.80 \pm 3.3$ & 3.5 & 9.0 & $6.15 \pm 6.6$ & 7.1 & 9.0 & $8.03 \pm 3.3$ & 3.5 & 9.0 & $6.31 \pm 3.3$ \\
\hline $\begin{array}{ll}\text { TL } & \text { SL } \\
\text { Proportion } & \end{array}$ & 62.12 & 82.14 & $67.17 \pm 0.75$ & $\begin{array}{l}61.1 \\
2\end{array}$ & 83.33 & $71.82 \pm 1.32$ & 62.12 & 69.35 & $66.09 \pm 0.39$ & 62.12 & 83.33 & $91.40 \pm 1.32$ \\
\hline $\begin{array}{ll}\mathrm{TL}- & \mathrm{HL} \\
\text { Proportion } & \end{array}$ & 28.18 & 37.86 & $32.60 \pm 0.35$ & $\begin{array}{l}22.0 \\
0\end{array}$ & 37.86 & $31.00 \pm 0.69$ & 30.89 & 36.21 & $32.62 \pm 0.28$ & 25.52 & 37.86 & $32.03 \pm 0.56$ \\
\hline $\begin{array}{ll}\text { SL } & \text { BD } \\
\text { Proportion } & \end{array}$ & 40.5 & 81.36 & $61.40 \pm 1.75$ & $\begin{array}{l}32.4 \\
8\end{array}$ & 68.89 & $50.30 \pm 2.11$ & 53.68 & 81.36 & $62.44 \pm 1.59$ & 32.48 & 68.89 & $51.87 \pm 2.02$ \\
\hline $\begin{array}{lll}\text { HL - } & \text { ED } \\
\text { Proportion } & \\
\end{array}$ & 17.92 & 27.41 & $20.31 \pm 0.38$ & $\begin{array}{l}17.9 \\
2 \\
\end{array}$ & 35.13 & $24.18 \pm 1.02$ & 18.36 & 24.04 & $20.31 \pm 0.31$ & 17.92 & 35.13 & $22.64 \pm 0.85$ \\
\hline $\begin{array}{ll}\text { SL } \quad- & \text { HL } \\
\text { Proportion } & \end{array}$ & 36.05 & 52.68 & $48.66 \pm 0.55$ & $\begin{array}{l}27.9 \\
5\end{array}$ & 52.68 & $43.68 \pm 1.3$ & 46.32 & 52.68 & $49.36 \pm 0.35$ & 31.62 & 52.68 & $45.40 \pm 1.17$ \\
\hline $\begin{array}{l}\text { HL - } \quad \text { BD } \\
\text { Proportion }\end{array}$ & 51.04 & 94.13 & $80.77 \pm 10.98$ & $\begin{array}{l}72.2 \\
6\end{array}$ & $\begin{array}{l}103.0 \\
8\end{array}$ & $88.32 \pm 1.71$ & 57.04 & 98.13 & $80.52 \pm 2.05$ & 72.26 & $\begin{array}{l}103.1 \\
7\end{array}$ & $89.10 \pm 1.83$ \\
\hline $\begin{array}{ll}\text { TL }- & \text { PCL } \\
\text { Proportion } & \end{array}$ & 23.37 & 30.71 & $25.00 \pm 0.28$ & $\begin{array}{l}21.9 \\
0\end{array}$ & 26.39 & $24.52 \pm 0.40$ & 23.33 & 26.32 & $25.17 \pm 0.20$ & 21.95 & 30.71 & $24.44 \pm 0.41$ \\
\hline & & & & & & & & & & & & \\
\hline
\end{tabular}

The meristic characters of L.goreensis were 10 dorsal spines and 14 rays in the posterior dorsal fin. (Table II). The Anal spine had 3 pieces of spine while 8 rays were found in the posterior anal fin. The scale of the fish ranges between 36 and 60 with a mean range of $55.66 \pm 6.67$.

Two-way t-analysis on the fin spine and rays counts among the populations of this species from the two stations indicated that the calculated (t-test) values were 0.00 and 0.00 respectively, when the t-crit values @ $\mathrm{P}=0.05$, df $=58$ was 2.010. Hence, data showed that there were no significant different in numbers of spines and rays count in the anterior and posterior dorsal and anal fin of the fish from the two stations in the Lagoon. The scales had between $36-60$ scales along the lateral line. The calculated t-test valves for the scale count from the station were 0.00 and 0.00 respectively, the t-crit valves $@ \mathrm{P}=0.05$, df $=58$ was 2.010 . Hence there was no significant different $(\mathrm{P}>0.05)$ in number of scales of the fish in Lagos Lagoon, Nigeria.

The meristic characters of L.agennes were 10 dorsal spines and 14 rays in the posterior dorsal fin (Table II). The anal spine had 3 pieces of the spines while 8 rays were found in the posterior anal fin. The scale of the fish ranges between 36 and 58 with a mean range of $46.66 \pm 3.33$.

Two-way, $t$ - analysis on the fin spine and ray counts among the populations of this species from the two stations indicated that the calculated t-test valves were 0.00 and 0.00 respectively, when the t-crit valves @ $\mathrm{P}=$ $0.05, \mathrm{df}=58$ was 2.010. Hence, data showed that there were no significant different in number of spines and rays counts in the anterior and posterior dorsal and anal fin of the fish from the two stations in the Lagoon.

The scales had between $36-58$ scales along the lateral line. The calculated t-test valves for the scale count from the stations were 0.00 and 0.00 respectively, the t-crit valves $@ \mathrm{P}=0.05, \mathrm{df}=58$ was 2.010 . Hence there was no significant difference $(\mathrm{P}>0.05)$ in number of scales of the fish in Lagos Lagoon, Nigeria. 
Table II The meristics counts of L.goreensis and L.agennes from (2) two sampling stations (Lekki lagoon and Badagry creek) of Lagos State, Nigeria.

\begin{tabular}{|l|l|l|l|l|l|l|l|l|l|l|l|l|l|}
\hline \multirow{2}{*}{$\begin{array}{c}\text { MERISTIC } \\
\text { CHARACTERS }\end{array}$} & \multicolumn{4}{|c|}{ LEKKI LAGOON } & \multicolumn{3}{c|}{ BADAGRY LAGOON } & \multicolumn{3}{c|}{ LEKKI LAGOON } & \multicolumn{2}{c|}{ BADAGRY } \\
LAGOON
\end{tabular}

\section{Discussion}

In the present study the morphometric measurements among the species of L.goreensis and L.agennes from the two sampling stations did show some varaiations, however, these variations were not significantly different $(\mathrm{p}>0.05)$ enough to make a submission that the species were genetically or morphologically different. Data of L.goreensis on eye diameter $(1.7-2.5 \mathrm{~cm})$, head length $(8.8-11.2 \mathrm{~cm})$, standard length $(19-23.5 \mathrm{~cm})$, Body depth $(10.2-17.9 \mathrm{~cm})$, Total length $(28.5-35 \mathrm{~cm})$, and pectoral length $(7.1-9.0)$. While that of L.agennes on eye diameter( $1.3-2.2 \mathrm{~cm})$, head length $(3.7-11.2 \mathrm{~cm})$, standard length $(11.7-23 \mathrm{~cm})$, body depth $(3.8-$ $15.5 \mathrm{~cm})$ Total length $(14.2-35 \mathrm{~cm})$ and pectoral length $(3.5-9.0 \mathrm{~cm})$, all these may not be fully relied on as determinants for genetic diversity, but their importance in taxonomic characterization of this species cannot be over emphasized. Proportionally (Table I) total length measurement were $66.09-67.17$ times the standard length, and $32.60-32.62$ times the head length and also $25.0-25.17$ times the pectoral length. The standard length was $61.40-62.44$ times the body depth and $48.66-49.36$ times the head length. The head length was 20.31 times the eye diameter and $80.52-80.77$ times the body depth in L.goreensis. While also in the same table 1, L.agennes Total length measurement was 91.40 - 91.82 times the standard length and $31.00-32.07$ times the head length and also $24.44-24.52$ times the pectoral length.The standard length was $50.30-51.87$ times the body depth and 43.68 - 45.40 times the head length. The head length was $22.64-24.18$ times the eye diameter and 88.32 - 89.10 times the body depth in lekki lagoon and badagry creek respectively. Data from these parameters suggest that the fish species from the sampling stations were not seperable taxonomically. These body proportion showed little variations among the specimens from the stations that were also not significantly different $(\mathrm{p}>0.05)$.

The meristic characters (Table II) i.e numbers of dorsal spine (10) and dorsal fins (14 rays) and anal spine (3), anal fins (8 rays) were not significantly different in both species of L.goreensis and L. agennes from the two stations. The scale count in L.goreensis ranges between $36-60$ while in L.agennes ranges between $36-58$, these shows there were no significant difference in scale count between the 2 species of fish from the two stations. Taxonomical and morphological features such as numbers of dorsal and anal fins, numbers of scales on the lateral line and external morphology were employed by Jaafar et al (2006) in Singapore to differentiate between two species of lutjanids, Lutjanus dentatus and Lutjanus goreensis. Meristic counts are based on more primitive characters than morphometric measurements and would therefore provide stronger evidence for speciation. In addition, species status would only be accepted if there was no overlap in the range of at least one of the meristic character or morphometric ratios investigated (Richardson 2010). Tobor and Ajayi,(1979), and Schneider (1990) at different periods worked on this species in different Nigerian waters. The morphometric measurement and meristic counts of these species in Lekki and Badagry lagoon did not show that the fish was taxonomically seperable based on our methods. The species among the two(2) sampling stations in the lagoon though showed variations in their morphometric measurement but these did not differ significantly $(p>0.05)$, indicating that the species from the stations may not be genetically diversified. These insignificant variations may be due to the geographical, ecology and human activities in the lagoon.

In the present study no taxonomic variations were detected among the species. L.goreensis and L.agennes may probably be the only species in Lekki lagoon and Badagry creek.

Data obtained from this work will serve as template in systematic study and taxonomy of this and non - related fishes. In furtherance of this, a research programme should be embarked on at molecular level of analysis (e.g Randomly Amplified Polymorphic DNA (RAPD) primers, RAPD markers) which may provide better or more precise result on genetic and morhphological diversities among the species of this fish in Lekki lagoon and Badagry creek. Nigeria 


\section{Conclusion}

In the present study there was no significant differencies between the two species of $L$. goreensis and $L$. agennes which could not be a basis for identification of the lutjanids.

In furtherance of this work, a research programme must be embarked upon at molecular level of analysis (e.g. Randomly Amplified Polymorphic DNA (RAPD) primers, RAPD markers) which may provide better or more precise results on genetic and morphological diversities among the species of this fishes in Lagos Lagoon, Nigeria.

\section{References}

[1]. Aas (2002). The next chapter: Multicultural and Cross - disciplinary progress in evaluating recreational fisheries. In; Pitcher T.J. Hollingworth CE (eds). Recreational Fisheries: ecological, economic and social evaluation. Oxford: Blackwell Publishing. PP252 263.

[2]. Allen G.R (1985). FAO species catalogue.Snappers of the World. An annotate and illustrated catalogue of Lutjanid species known to date. FAO Fish Synop (6) 125: - 208 pp.

[3]. Anderson, W.D.J (1967). Field guide to the snappers (Lutjanidae) of the Western Atlantic U.S, Fish Wild. Serv. Circ. 252. 14 pp

[4]. .Bagenal T.B (1978): Methods for Assessment of fish production in Freshwaters, Blackwell Scientific Publications Ltd; London 273 pp

[5]. Beaumariage.D.S., and A.C Wittish. (1966). Returns from the 1964 Schlitz tagging program. Fla. Board Con-Serv. Mar. Res. Lab. Tech. Serv. 47-51 pp

[6]. Bradley, E., and C.E Bryan (1995): Life history and fishery of the red snapper (Lutjanus campechanus) in the North Western Gulf of Mexico: 1970 - 1974. Proc. Gulf Carrib. Fish Inst. 27: 77 - 106 pp.

[7]. Eyo, A. A. (2010): Fish processing Technology in the Tropic University of Ilorin press. 403pp.

[8]. Fafioye O.O and Oluajo, O.A (2005), Diaz et al (20000. Length - weight relationships of five species in Epe lagoon. Nigeria African Journal of Bio technology 4(7) 749 - 751pp

[9]. Futch R.B., and G.E Bruger. (1976). Age, growth and reproduction of red snapper in Florida waters. Pages $165-184$ in H.R Bullis, Jr. and A.C Jones, eds. Proceedings colloquim on snapper - grouper Fishery resources of the Western Central Atlantic Ocean. Fla. Sea group Grant cou.Rep.17. 333pp.

[10]. Holden, M and Reed, W (1972). West African Fresh water Fish. Longman Group Ltd. 65 Pp.

[11]. Kochzius, M (1997): Length - weight Relationship of fishes from a seagrass Meadow in Negros Oriental, Philippines, NAGA: ICLARM Quarterly. July - Dec. Pp. $64-65$.

[12]. Nelson.R.S and C.S Manooch. (1982). Growth and mortality of red snappers in the West Central Atlantic ocean and Northern Gulf of Mexico. Trans. Am. Fish, Soc. 111: $465-475$.

[13]. Olaosebikan, B.D and Raji A. (1998).Field Guide to Nigeria Freshwater Fishes. Federal College of Freshwater Fisheries Technology. New Bussa, Nigeria.106 Pp.

[14]. Olatunde, A.A. (1989) Some aspect of Biology of Synodontis schall (Bloch \&Schneider 1801) in Zaria. Journal of Aquatic Sciences.4:49-54.

[15]. Paulin R.S.V (1988) ed: Tilapia Genetic Resources for Agriculture Proceedings of the workshop on Tilapia Genetic Resources for aquaculture International centre for living Aquatic Resources Management (ICLARM) Conference Proceeding. 16 - 108 Pp.

[16]. Richardson, T.J. (2010). The taxonomy, life-history and population dynamics of blacktail Diplodus capensis (perciformes: sparidae), in southern angola. M.Sc. Rhodes University, South Africa. 157p.

[17]. $\quad$ Rivas, L.R (1966). Reviews of the LutjanusCompechanus Complex of red snappers Q.J. Fla. Acad. Sci. 29 (2) 117 - 136.

[18]. Roe, R.B (1976): Distribution of snappers and groupers in the Gulf of Mexico and Caribbean sea as determined from explanatory Fishing data. Pages 129 - 164 in H.R Bullis, Jr. and A.C Jones, eds. Proceedings: Colloquium on snapper - grouper fishery resources of the Western Central Atlantic Ocean.Fla sea Grant Coll. Rep 17. 333Pp.

[19]. Schneider, W. (1990). Field guide to commercial marine resources of the gulf of guinea. RAFR/FI/90/2. FAO, Rome.268pp.

[20]. Sparre, P. Venema SC (1995). Introduction to Tropical Fish Stock Assessment. Part 1. Manual, F.A.O Fish. Tech Paper No. 306. Rev. I. F.A.O Rome, Italy 372 Pp.

[21]. Spence J.T, Cotton J.N. Cotton J.W. Underwood, B.J and Duncan, C.P (1978); $3^{\text {rd }}$ Ed. Elementary Statistics.Century Psychology series. Prentice-Hall Inc, New Jersey. 295 Pp.

[22]. S.P.S.S.(2007): Statistical Package for Social scientists. S.P.S.S Base 15.0 User's Guide, copyright@ 2006. S.P.S.S. Inc. 233 South Wacker Drive, $11^{\text {th }}$ Floor, Chicago,

[23]. Szedlmayer.S.T and R.L Shipp (1994): Diet Stuffs of Juvenile red snapper (Lutjanus Campechamus) with changes in habitat and fish size. Fishery Bulletin 102: $366-375$.

[24]. Tobor, J.G and Ajayi, T.O. (1979). Notes on the identification of marine fishes found in the Nigerian coastal waters NIOMR Occasional Paper No.25

[25]. Topp, R and Fable (1980). The tagging of fishes in Florida. 1962 Program, Fla Board Conserv. Mar Lab. Prof. Pap. Serv. 5.76 Pp.

[26]. Vergara -R, R, Preparer (1978).Lutjanidae. In W. Fischer, ed. FAO Species identification sheets. Fishing area 31 (Western Central Atlantic). Food and Agriculture Organization of the United Nations, Rome. 